\title{
Pig performance increases with the addition of DL-methionine and L-lysine to ensiled cassava leaf protein diets
}

\author{
Nguyen Thi Hoa Ly $\cdot$ Le Duc Ngoan • \\ Martin Wilhelmus Antonius Verstegen • \\ Wouter Hendrikus Hendriks
}

Accepted: 27 May 2011 / Published online: 27 September 2011

(C) The Author(s) 2011. This article is published with open access at Springerlink.com

\begin{abstract}
Two studies were conducted to determine the impact of supplementation of diets containing ensiled cassava leaves as the main protein source with synthetic amino acids, DL-methionine alone or with L-lysine. In study 1 , a total of 40 pigs in five units, all cross-breds between Large White and Mong Cai, with an average initial body weight of $20.5 \mathrm{~kg}$ were randomly assigned to four treatments consisting of a basal diet containing $45 \%$ of dry matter (DM) from ensiled cassava leaves (ECL) and ensiled cassava root supplemented with $0 \%, 0.05 \%, 0.1 \%$ and $0.15 \%$ DL-methionine (as DM). Results showed a significantly improved performance and protein gain by extra methionine. This reduced the feed cost by $2.6 \%, 7.2 \%$ and $7.5 \%$, respectively. In study 2 , there were three units and in each unit eight cross-bred (Large White $\times$ Mong Cai) pigs with an initial body weight of $20.1 \mathrm{~kg}$ were randomly assigned to the four treatments. The four diets were as follows: a basal diet containing 15\% ECL (as DM) supplemented with different amounts of amino acids L-lysine and DL-methionine to the control diet. The results showed that
\end{abstract}

N. T. H. Ly $(\bowtie) \cdot$ L. D. Ngoan

Department of Animal Nutrition and Biochemistry,

Hue University of Agriculture and Forestry,

Hue City, Vietnam

e-mail: nguyenhoaly@gmail.com

M. W. A. Verstegen - W. H. Hendriks

Animal Nutrition group, Department of Animal Sciences,

Wageningen University,

Wageningen, The Netherlands

W. H. Hendriks

Department of Farm Animal Health,

Faculty of Veterinary Medicine, Utrecht University,

Utrecht, The Netherlands diets with $15 \%$ of DM as ECL with supplementation of $0.2 \%$ lysine $+0.1 \%$ DL-methionine and $0.1 \%$ lysine $+0.05 \%$ DL-methionine at the $20-50 \mathrm{~kg}$ and above $50 \mathrm{~kg}$, respectively, resulted in the best performance, protein gain and lowest costs for cross-bred (Large White $\times$ Mong Cai) pigs. Ensiled cassava leaves can be used as a protein supplement for feeding pigs provided the diets contain additional amounts of synthetic lysine and methionine.

Keywords Amino acids Ensiled cassava leaves · L-lysine . DL-methionine $\cdot$ Growing pigs $\cdot$ Protein deposition

\section{Introduction}

Cassava (Manihot esculenta Crantz) is an annually root crop grown widely in tropical and subtropical areas with the roots being a good source of energy while the leaves contain protein, vitamins and minerals. Cassava leaves have a high crude protein $(\mathrm{CP})$ content of which almost 0.85 is true protein (Ravindran 1993). Furthermore, cassava leaf protein has an essential amino acid (EAA) content which is higher than soybean protein (Eggum 1970; Phuc 2000; Montagnac et al. 2009). The high protein content and the relatively good EAA profile are reasons for the inclusion of cassava leaves as a protein source in diets for pigs in many countries. Cassava roots and leaves, however, contain large amounts of cyanogenic glucosides that give rise to toxic hydrocyanic acid (HCN) which limits the use of these products as an animal feed ingredient (Oke 1978; Ngudi et al. 2003; Cardoso et al. 2005). Ensiling cassava roots and leaves reduce the HCN content (Gomez et al. 1985; Phuc 2000; Loc 2004) and allow increased incorporation in animal feeds. 
Several studies have determined the ileal apparent digestibility of a number of protein-rich foliages (cassava leaves, leacaena leaves, groundnut foliage, sweet potato leaves) available in tropical countries (Phuc and Lindberg 2001; An et al. 2004; Nguyen et al. 2010a). In the case of cassava leaves, the first limiting amino acid for growing pigs is methionine closely followed by lysine (Chauynarong et al. 2009; Montagnac et al. 2009; Nguyen et al. 2010a). Methionine is not only required for growth and maintenance of body protein but also for in vivo detoxification of hydrogen cyanide (Job 1975; Tewe 1992) to non-toxic thiocyanate (Oke 1978) when pigs are fed cassava leaf or root ingredients. Although it is well-known that methionine is the first limiting amino acids in cassava protein for rats (Eggum 1970), little research has focused on the supplementation of diets containing ensiled cassava proteins with methionine or lysine on the performance of monogastric production animals. Loc (2004) reported studies in crossbred pigs (Large White $\times$ Mong Cai) fed ensiled cassava rootbased diets supplemented with methionine. Performance as measured by growth rate and feed conversion ratio were found to increase with DL-methionine supplementation. There have been no studies reported in the literature on the effects of pig performance and the economic viability of methionine and lysine addition to pig diets containing cassava protein.

The aim of the two studies reported here was to evaluate the effect of supplementation of synthetic DL-methionine alone or in combination with synthetic L-lysine to diets which contain ensiled cassava leaves (ECL) and ensiled cassava roots (ECR) as the major protein source in diets for pigs.

\section{Materials and methods}

The experiments reported here were carried out in eight units in the Huong Van commune, which is one of the main pig production areas of Thua Thien Hue province in Vietnam. The protocol of the study was approved by the ethical committee of Hue University, Hue, Vietnam.

Preparation and preservation of ensiled cassava leaves

Fresh leaves of cassava were collected at the time of root harvest and spread out for $5 \mathrm{~h}$ on the floor for wilting during which time the dry matter (DM) content increased from $24 \%$ to $28-29 \%$. After wilting, the leaves were separated from the stems and petioles, chopped into small pieces $(2-3 \mathrm{~cm})$, mixed with $0.5 \% \mathrm{NaCl}$ and rice bran at $5 \%$ of the wilted weight of the cassava leaves. The mixture was kept in air tight nylon bags with a capacity of $30 \mathrm{~kg}$ and stored during 2 months before use. This ensiling procedure resulted in a stable silage $\mathrm{pH}$ and a low cyanide content.

Animals, experimental design and feeding

\section{Study 1: DL-methionine supplementation}

Forty cross-bred pigs (Large White $\times$ Mong Cai) with an average initial body weight of $20.5 \mathrm{~kg}(\mathrm{SD}=0.7)$ and of similar ages were randomly allocated to five units. In each unit, eight pigs (four males and four females) were randomly allocated to one of four pens $(2 \times 1 \mathrm{~m})$, with two pigs (one male and one female) per pen. Each pen was randomly allocated to one of the four dietary treatments which differed in the level of DL-methionine supplementation $(0 \%, 0.05 \%, 0.10 \%$ and $0.15 \%)$ during two growing phases. Two control diets were formulated for the two growing periods, period 1 from 20 to $50 \mathrm{~kg}$ and period 2 above $50 \mathrm{~kg}$. The control diet (Table 1) consisted of rice bran, maize, ECR, ECL and fish meal (FM). Diets for each period included $15 \%$ and $30 \%$ of ECL and ECR, respectively on a DM basis. The control diet was formulated to contain 12.6 MJ ME, $14.1 \% \mathrm{CP}, 0.66 \%$ lysine and $0.28 \%$ methionine + cysteine in period 1 and $12.6 \mathrm{MJ} \mathrm{ME}, 12.2 \% \mathrm{CP}, 0.55 \%$ lysine and $0.25 \%$ methionine + cysteine in period 2 . The chemical composition of the feed ingredients used to formulate the diets in study 1 is shown in Table 2 .

\section{Study 2: DL-methionine and L-lysine supplementation}

Twenty four cross-bred pigs (12 males and 12 females) (Large White $\times$ Mong Cai) with an average initial weight of $20.1 \mathrm{~kg}(\mathrm{SD}=0.2)$ and of similar ages were randomly allocated according to gender to three units. The eight pigs (four males and four females) per unit were randomly allocated to four pens $(2 \times 1 \mathrm{~m})$, with two pigs (one male and one female) per pen. Each pen was randomly allocated to one of the four dietary treatments with different levels of supplemented L-lysine and DL-methionine. Throughout the growing period, pigs were fed the basal diets depending on body weight (20 to $50 \mathrm{~kg}$ and above $50 \mathrm{~kg}$ ). The control diet consisted of rice bran, maize, ECR, ECL and FM and included on a dry matter basis $15 \%$ of ECL and ECR $17 \%$ of DM for period 1 and $25 \%$ in period 2 (see Table 3). During period 1, the control diet contained 12.6 MJ ME, $14.9 \%$ CP, $0.70 \%$ lysine and $0.28 \%$ methionine while during period 2 the diet contained 12.6 MJ ME, $12.8 \%$ CP, $0.58 \%$ lysine and $0.23 \%$ methionine (Table 3 ). The control diet was supplemented with no, low, medium or high levels of L-lysine and DL-methionine. The low amino acid diet was supplemented with $0.10 \%$ and $0.05 \%$ L-lysine and DL-methionine, respectively during period 1 and during 
Table 1 Ingredient content (percent), chemical composition (\% DM), calculated metabolisable energy content (megajoules per kilogramme DM) and hydrogen cyanide content (milligrammes per kilogramme DM) of the experimental diets for the pigs in study 1

\footnotetext{
${ }^{a}$ Ninety-eight percent DL-methionine (Sunmitomo Chemical Co., Ltd./Ajinomoto Co., Inc, Japan)

${ }^{\mathrm{b}}$ Calculated values based on analysed crude protein and amino acid composition and apparent ileal digestibility data from Nguyen et al. (2010a) and Ngoan and Lindberg (2001)
}

\begin{tabular}{|c|c|c|c|c|c|c|c|c|}
\hline \multirow[t]{4}{*}{ Ingredient/component } & \multicolumn{8}{|l|}{ Diet } \\
\hline & \multicolumn{4}{|c|}{20 to $<50 \mathrm{~kg}$} & \multicolumn{4}{|c|}{$>50 \mathrm{~kg}$} \\
\hline & \multirow[t]{2}{*}{ Basal } & \multicolumn{3}{|c|}{ + DL-methionine } & \multirow[t]{2}{*}{ Basal } & \multicolumn{3}{|c|}{ + DL-methionine } \\
\hline & & 0.05 & 0.10 & 0.15 & & 0.05 & 0.10 & 0.15 \\
\hline Rice bran & 29 & 29 & 29 & 29 & 30 & 30 & 30 & 30 \\
\hline Yellow maize & 18 & 18 & 18 & 18 & 21 & 21 & 21 & 21 \\
\hline Ensiled cassava roots & 30 & 30 & 30 & 30 & 30 & 30 & 30 & 30 \\
\hline Ensiled cassava leaves & 15 & 15 & 15 & 15 & 15 & 15 & 15 & 15 \\
\hline Fish meal & 8 & 8 & 8 & 8 & 4 & 4 & 4 & 4 \\
\hline DL-methionine $^{\mathrm{a}}$ & - & 0.05 & 0.10 & 0.15 & - & 0.05 & 0.10 & 0.15 \\
\hline \multicolumn{9}{|l|}{ Chemical composition } \\
\hline Metabolisable energy & 12.6 & 12.6 & 12.6 & 12.6 & 12.6 & 12.6 & 12.6 & 12.6 \\
\hline Crude protein & 14.1 & 14.1 & 14.1 & 14.1 & 12.2 & 12.2 & 12.2 & 12.2 \\
\hline Crude fibre & 6.8 & 6.8 & 6.8 & 6.8 & 6.9 & 6.9 & 6.9 & 6.9 \\
\hline Lysine & 0.66 & 0.66 & 0.66 & 0.66 & 0.55 & 0.55 & 0.55 & 0.55 \\
\hline Methionine + cysteine & 0.28 & 0.33 & 0.38 & 0.43 & 0.25 & 0.30 & 0.35 & 0.40 \\
\hline \multicolumn{9}{|l|}{ Ileal digestible $\mathrm{e}^{\mathrm{b}}$} \\
\hline Lysine & 0.51 & 0.51 & 0.51 & 0.51 & 0.44 & 0.44 & 0.44 & 0.44 \\
\hline Methionine + cysteine & 0.21 & 0.26 & 0.31 & 0.36 & 0.19 & 0.24 & 0.29 & 0.34 \\
\hline Hydrogen cyanide & 43.5 & 43.5 & 43.5 & 43.5 & 43.5 & 43.5 & 43.5 & 43.5 \\
\hline
\end{tabular}

period 2 with $0.05 \%$ L-lysine and $0.03 \%$ DL-methionine. In the medium supplemented diet in periods 1 and 2, $0.20 \%$ and $0.10 \%$ L-lysine and $0.10 \%$ and $0.05 \%$ DL-methionine, respectively were added to the basal diet. The high supplemented diet was obtained by adding $0.30 \%$ L-lysine and $0.15 \%$ DL-methionine during period 1 and with $0.15 \%$ L-lysine and $0.08 \%$ DL-methionine during period 2 . The dietary composition of the eight diets is given in Table 3 .

In both studies, the pigs had been vaccinated against hog cholera and Pasteurellosis, and had been dewormed 2 weeks before starting the experiment. The composition of the control diets for the two growing periods in both studies is given in Table 2. The diets were fed at a level of $4 \%$ of body weight
(BW) as recommended by the National Institute of Animal Husbandry (NIAH 2001). Both experiments lasted 90 days and were conducted during the cool season in Vietnam with average daily temperatures between $22^{\circ} \mathrm{C}$ and $26^{\circ} \mathrm{C}$. The diets were distributed equally into three meals per day $(7,11$ and $17 \mathrm{~h}$ ) with refusals collected the following morning before the first meal. Drinking water was provided ad libitum.

\section{Chemical analyses}

The feedstuffs in the experimental diets were analysed for DM, crude protein (CP), crude fibre and HCN (AOAC 1990) and amino acids. DM was measured by drying fresh

Table 2 Dry matter and chemical composition of the dietary ingredient used to formulate the experimental diets

\begin{tabular}{|c|c|c|c|c|c|c|c|c|c|c|}
\hline \multirow[t]{2}{*}{ Component } & \multicolumn{2}{|c|}{ Rice bran } & \multicolumn{2}{|c|}{ Yellow corn } & \multicolumn{2}{|l|}{ ECR } & \multicolumn{2}{|l|}{ ECL } & \multicolumn{2}{|c|}{ Fish meal } \\
\hline & Exp 1 & $\operatorname{Exp} 2$ & Exp 1 & $\operatorname{Exp} 2$ & Exp 1 & $\operatorname{Exp} 2$ & Exp 1 & $\operatorname{Exp} 2$ & Exp 1 & $\operatorname{Exp} 2$ \\
\hline Dry matter $(\%)$ & 88.0 & 86.3 & 85.5 & 84.4 & 40.6 & 41.0 & 28.0 & 32.8 & 90.0 & 90.0 \\
\hline Crude protein $(\% \mathrm{DM})$ & 11.3 & 11.4 & 9.8 & 9.9 & 3.0 & 3.1 & 23.0 & 20.8 & 58.5 & 58.5 \\
\hline Crude fibre (\% DM) & 9.7 & 9.8 & 2.8 & 2.8 & 4.0 & 3.9 & 15.0 & 12.8 & ND & ND \\
\hline Lysine (g/kg DM) & 4.8 & 4.9 & 3.2 & 3.3 & 1.2 & 1.1 & 11.5 & 10.8 & 31.6 & 31.6 \\
\hline Methionine + cysteine $(\mathrm{g} / \mathrm{kg} \mathrm{DM})$ & 2.3 & 2.3 & 2.0 & 2.0 & 0.11 & 0.1 & 4.6 & 3.8 & 10.5 & 10.5 \\
\hline Metabolisable energy (MJ/kg DM) & 12.1 & 12.1 & 15.4 & 15.4 & 12.4 & 12.4 & 9.7 & 9.6 & 14.3 & 14.3 \\
\hline Hydrogen cyanide (mg/kg DM) & ND & ND & ND & ND & 29 & 29 & 232 & 162 & ND & ND \\
\hline
\end{tabular}

Exp experiment, ECR ensiled cassava root, $E C L$ ensiled cassava leaves analysed at 60 days after ensiling, $N D$ not determined 
Table 3 Ingredient content (percent), chemical composition (\% of DM), calculated metabolisable energy content (megajoules per kilogramme DM) and hydrogen cyanide content (milligrammes per kilogramme DM) of the experimental diets for the pigs in study 2

${ }^{a}$ Ninety-nine percent L-lysine HCL (Sunmitomo Chemical Co., Ltd/Ajinomoto Co., Inc., Japan)

${ }^{\mathrm{b}}$ Ninety-eight percent DL-methionine (Sunmitomo Chemical Co., Ltd./Ajinomoto Co., Inc., Japan)

${ }^{\mathrm{c}}$ Calculated values based on analysed crude protein and amino acid composition and apparent ileal digestibility data of Nguyen et al. (2010a) and Ngoan and Lindberg (2001)

\begin{tabular}{|c|c|c|c|c|c|c|c|c|}
\hline \multirow[t]{4}{*}{ Ingredient/component } & \multicolumn{8}{|l|}{ Diet } \\
\hline & \multicolumn{4}{|c|}{20 to $<50 \mathrm{~kg}$} & \multicolumn{4}{|c|}{$>50 \mathrm{~kg}$} \\
\hline & \multirow[t]{2}{*}{ Basal } & \multicolumn{3}{|c|}{ + L-lysine and DL-methionine } & \multirow[t]{2}{*}{ Basal } & \multicolumn{3}{|c|}{+ L-lysine and DL-methionine } \\
\hline & & Low & Medium & High & & Low & Medium & High \\
\hline Rice bran & 40 & 40 & 40 & 40 & 35 & 35 & 35 & 35 \\
\hline Yellow maize & 20 & 20 & 20 & 20 & 20 & 20 & 20 & 20 \\
\hline Ensiled cassava roots & 17 & 17 & 17 & 17 & 25 & 25 & 25 & 25 \\
\hline Ensiled cassava leaves & 15 & 15 & 15 & 15 & 15 & 15 & 15 & 15 \\
\hline Fish meal & 8 & 8 & 8 & 8 & 5 & 5 & 5 & 5 \\
\hline L-lysine $e^{a}$ & - & 0.10 & 0.20 & 0.30 & - & 0.05 & 0.10 & 0.15 \\
\hline DL-methionine $\mathrm{e}^{\mathrm{b}}$ & - & 0.05 & 0.10 & 0.15 & - & 0.03 & 0.05 & 0.08 \\
\hline \multicolumn{9}{|l|}{ Chemical composition } \\
\hline Metabolisable energy & 12.6 & 12.6 & 12.6 & 12.6 & 12.6 & 12.6 & 12.6 & 12.6 \\
\hline Crude protein & 14.9 & 14.9 & 14.9 & 14.9 & 12.8 & 12.8 & 12.8 & 12.8 \\
\hline Crude fibre & 7.1 & 7.1 & 7.1 & 7.1 & 6.9 & 6.9 & 6.9 & 6.9 \\
\hline Lysine & 0.70 & 0.80 & 0.90 & 1.00 & 0.58 & 0.63 & 0.68 & 0.73 \\
\hline Methionine + cysteine & 0.28 & 0.33 & 0.38 & 0.43 & 0.23 & 0.26 & 0.28 & 0.31 \\
\hline \multicolumn{9}{|l|}{ Ileal digestible ${ }^{c}$} \\
\hline Lysine & 0.52 & 0.62 & 0.72 & 0.82 & 0.43 & 0.48 & 0.53 & 0.58 \\
\hline Methionine + cysteine & 0.21 & 0.26 & 0.31 & 0.36 & 0.18 & 0.21 & 0.23 & 0.26 \\
\hline Hydrogen cyanide & 29.3 & 29.3 & 29.3 & 29.3 & 31.7 & 31.7 & 31.7 & 31.7 \\
\hline
\end{tabular}

samples at $105^{\circ} \mathrm{C}$ for $24 \mathrm{~h}$. Total nitrogen (N) was determined on fresh samples by the macro Kjeldahl method and $\mathrm{CP}$ was calculated from total nitrogen $\left(\mathrm{N}^{*} 6.25\right)$. Amino acids were analysed according to Spackman et al. (1958) on an ion-exchange column using an HPLC. Samples were hydrolysed for $24 \mathrm{~h}$ at $110^{\circ} \mathrm{C}$ with $6 \mathrm{M}$ HCL containing $2 \mathrm{~g} / \mathrm{L}$ reagent grade phenol and $5 \mu \mathrm{mol}$ norleucine (internal standard) in evacuated and sealed ignition tubes. Methionine+cysteine were determined as methionine sulphone and cysteic acid with separate samples hydrolyzed for $24 \mathrm{~h}$ as described above following oxidation with performic acid overnight at $0^{\circ} \mathrm{C}$ (Moore 1963). The $\mathrm{HCN}$ content was determined in the fresh ensiled samples by titration with $\mathrm{AgNO}_{3}$ after boiling the samples and concentrating the $\mathrm{HCN}$ in $\mathrm{KOH}$ (AOAC 1990). All samples were analysed in triplicate except amino acids which were analysed in duplicate. Most analyses were done in the Hue University laboratories except the amino acids (AAs) which were analysed at the National Institute of Animal Husbandry laboratories (Ha Noi).

\section{Measurements}

Feed consumption was determined by weighing the amounts given and subtracting any feed remaining the following morning. The pigs were individually weighed at the start of the study, monthly and at slaughter, and the average daily gain (ADG), dry matter intake and feed conversion ratio (FCR) were calculated for each treatment. Feed costs were calculated for the quantity of feed consumed by each pig, the individual feed ingredient prices and the composition of the feed.

Protein and fat deposition was calculated using the following assumptions: one gramme of protein and fat contains 23.4 and $39.7 \mathrm{~kJ}$ of energy per gramme, respectively (NRC 1998) and $\mathrm{ME}$ intake $=\mathrm{MEm}+c \times$ protein deposition $+d \times$ fat deposition where MEm is the amount of ME required for maintenance (460 kJ of ME per $\mathrm{kg}$ of metabolic $\left.\mathrm{BW}\left(\mathrm{BW}^{0.75}\right)\right) ; c$ and $d$ represent the amount of ME needed for the deposition of $1 \mathrm{~g}$ of protein and fat, respectively. The required amounts of ME needed to deposit protein and fat deposition (MEp) was assumed to be $53 \mathrm{~kJ}$ ME per g protein and $53 \mathrm{~kJ}$ per gramme of fat (NRC 1998).

On the basis of the literature review of Kotarbinska and Kielanowski (1969), it can be assumed that about $10 \%$ of weight gain is gut fill and ash, thus:

$0.9 \times \mathrm{ADG}=$ water + protein + fat.

The deposition rate of protein and fat in the empty body of the pig was calculated based on the following two equations:

$0.9 \times \mathrm{ADG}=F+P / 0.21$ 
$\mathrm{MEp}=F \times 53+P \times 53$

where ADG is the average rate of gain (grammes/day), 0.21 is the ratio of protein to protein + water, $F$ is the amount of fat deposited (grammes/day), $P$ is the amount of protein deposited (grammes/day) and MEp the metabolizable energy used for fat and protein deposition.

Statistical analysis

The experimental unit was a pen (two pigs). An analysis of variance was done according to the following model:

$Y_{\mathrm{ij}}=\mu+T_{\mathrm{i}}+e_{\mathrm{ij}}$

where $Y$ is a dependent variable, $\mu$ is the overall mean, $T_{\mathrm{i}}$ is the treatment effect $(i=1,2,3 \ldots 4)$ and $e_{\mathrm{ij}}$ is the random error.

Data were analysed by ANOVA using the general linear model of the Minitab Statistical Software version 14 (2004). A Tukey pairwise comparison was used to determine the differences between the treatment means at $P<0.05$.

\section{Results}

Study 1

The data in Table 4 indicate that supplementing diets containing $45 \%$ (in DM) of ensiled cassava (30\% ECR+ $15 \%$ ECL) with $0.05 \%, 0.1 \%$ and $0.15 \%$ DL-methionine significantly increased the final $\mathrm{BW}, \mathrm{ADG}$, and decreased the FCR in the pigs. The ADG differed between treatments $(P<0.001)$ and were 534, 560, 596 and $608 \mathrm{~g} /$ day for the control, $+0.05 \%$ met, $+0.10 \%$ met and $+0.15 \%$ met, respectively. The FCR for these groups were 2.97, 2.86, 2.69 and $2.65 \mathrm{~kg}$ DM per kilogramme gain, respectively $(P<0.001)$. The data in Table 4 show that protein deposition of the $F_{1}$ pigs used increased significantly while the fat deposition was decreased as levels of supplementary DL-methionine increased in the diet. The protein deposition of the pigs fed the control, control+ $0.05 \%$ met, $+0.10 \%$ met and $+0.15 \%$ met diet were 60.2 , $66.3,75.1$ and $77.5 \mathrm{~g} /$ day, respectively $(P<0.001)$.

Supplementing diets containing 45\% (in DM) ensiled cassava $(30 \% \mathrm{ECR}+15 \% \mathrm{ECL})$ with DL-methionine at levels of $0.05 \%, 0.10 \%$ and $0.15 \%$ gave lower feed costs by $2.6 \%, 7.2 \%$ and $7.5 \%$, respectively. Differences in feed cost per kilogramme weight gain were significant among the treatments $(P<0.005)$. The feed cost per kilogramme gain for the control $+0.15 \%$ met diet was lowest although this was not significantly different from the control $+0.10 \%$ met diet.

Study 2

The effects of the supplementation of the diets containing $15 \%$ ECL in the DM with L-lysine and DL-methionine on the performance of pigs are shown in Table 5.

The final BW and ADG were highest for pigs fed with the two highest levels of supplementary L-lysine plus DLmethionine. The FCR was higher in the control diet than in

Table 4 Performance and feed costs of growing (20-80 kg) Large White $\times$ Mong Cai pigs fed diets containing ensiled cassava leaves and supplemented with different levels of DL-methionine in study 1

\begin{tabular}{|c|c|c|c|c|c|c|}
\hline \multirow[t]{3}{*}{ Parameter } & \multicolumn{6}{|l|}{$\operatorname{Diet}^{\mathrm{a}}$} \\
\hline & \multirow[t]{2}{*}{ Basal } & \multicolumn{3}{|c|}{ + DL-methionine } & \multirow[t]{2}{*}{ SEM } & \multirow[t]{2}{*}{$P$} \\
\hline & & 0.05 & 0.10 & 0.15 & & \\
\hline Initial body weight (kg) & 20.1 & 20.8 & 20.6 & 20.2 & 0.3 & 0.213 \\
\hline Final body weight (kg) & $68.2 \mathrm{a}$ & $71.2 \mathrm{ac}$ & $74.2 \mathrm{bc}$ & $74.9 \mathrm{~b}$ & 1.0 & 0.001 \\
\hline Average daily gain (g/day) & $534 \mathrm{a}$ & $560 \mathrm{ac}$ & $596 \mathrm{bc}$ & $608 b$ & 12 & 0.001 \\
\hline Dry matter intake (kg/day) & 1.59 & 1.60 & 1.61 & 1.62 & 0.02 & 0.475 \\
\hline Feed conversion ratio ( $\mathrm{kg} \mathrm{DM} / \mathrm{kg}$ gain) & $2.97 \mathrm{a}$ & $2.86 \mathrm{a}$ & $2.69 b$ & $2.65 b$ & 0.05 & 0.001 \\
\hline \multicolumn{7}{|l|}{ Calculated deposition (g/day) } \\
\hline Protein & $60.2 \mathrm{a}$ & $66.3 \mathrm{a}$ & $75.1 \mathrm{~b}$ & $77.5 b$ & 2.5 & 0.001 \\
\hline Fat & $194.3 \mathrm{a}$ & $188.1 \mathrm{ab}$ & $179.1 \mathrm{~b}$ & $178.4 \mathrm{~b}$ & 3.6 & 0.009 \\
\hline Feed $\operatorname{cost}^{\mathrm{a}}$ (VND/kg gain) & $6,289 \mathrm{a}$ & $6,126 \mathrm{a}$ & $5,837 \mathrm{~b}$ & $5,816 \mathrm{~b}$ & 102 & 0.005 \\
\hline Costs compared to control (\%) & 100 & 97.4 & 92.8 & 92.5 & - & - \\
\hline
\end{tabular}

Means with different letters within rows differ $(P<0.05)$

${ }^{a}$ Price of feed ingredients at Hue during the time of the study in Viet Nam Dong (VND per kilogramme): ensiled cassava roots, 400; ensiled cassava leaves, 500; rice bran, 2,000; maize, 2,000; fish meal, 6,000; DL-methionine, 52,000. At the time of this study: US $\$ 1=15,000$ VND 
the other three diets supplemented with L-lysine and DLmethionine. The final $\mathrm{BW}$ and $\mathrm{ADG}$ of the pigs were highest, and the FCR was lowest at the medium level of Llysine and DL-methionine supplementation in the diet. Similarly, the estimated protein depositions of $F_{1}$ pigs was increased significantly $(P<0.001)$ when both L-lysine and DL-methionine were added to the diets. Protein deposition of the pigs fed the control diet + supplementary L-lysine and DL-methionine at the medium level was higher than for the other three treatments. The protein deposition of the pigs fed the control diet+supplementary L-lysine and DLmethionine at the high level was lower than that of pigs fed the control diet+supplementary L-lysine and DLmethionine at the level medium. A trend $(P<0.099)$ was observed in the feed costs per kilogramme gain with the medium supplementary L-lysine and DL-methionine diets having the lowest value.

\section{Discussion}

Cassava is a major staple root crop in many tropical and subtropical, developing countries. It is well-known that cassava roots are high in starch but low in crude protein, while cassava leaves are rich in crude protein. The protein quality of a food is the product of its AA content and the nutritional availability of these AAs. Eggum (1970) and Phuc (2000) reported that the concentration of the sulphur-containing amino acids is low in cassava leaves and roots which cause a relatively low biological value of this protein ranging from 44 to 57 . Recently, several researchers have reported that methionine is the most limiting AA both in cassava leaves and roots for growing pigs and poultry, followed by lysine (Loc 2004; Chauynarong et al. 2009; Montagnac et al. 2009; Nguyen et al. 2010a). In addition, the high cyanide content further limits the use of cassava leaves as a protein source in diets for pigs. Methionine not only plays a role as an EAA in protein deposition but is also important in the hydrogen cyanide detoxification process, particularly in rations with high levels of cassava roots or leaves. Therefore, pig diets with a high inclusion level of cassava root and leaves could benefit from additional supplementation with synthetic methionine and lysine. In order to determine the magnitude of the effect of supplementation, we formulated diets to contain $45 \%$ of ensiled cassava root and leaves and added increasing levels of supplementary DL-methionine (from $0 \%$ to $0.15 \%$ in $\mathrm{DM}$ ) to diets for growing pigs. The results show that there were significant effects of the diet on the final BW, ADG, FCR and protein deposition. Increasing levels of supplementary DL-methionine from $0.05 \%$ up to $0.15 \%$ in the diets improved ADG and FCR. These results can be explained by the fact that the supplemental methionine was not used for protein deposition and provided sulfydril groups $(-\mathrm{SH})$ necessary for the detoxification of cyanide as the HCN content of the

Table 5 Performance and feed costs of growing (20-80 kg) Large White x Mong Cai pigs fed diets containing ensiled cassava leaves and supplemented with different levels of L-lysine and DL-methionine in study 2

\begin{tabular}{|c|c|c|c|c|c|c|}
\hline \multirow[t]{3}{*}{ Parameter } & \multicolumn{6}{|l|}{$\operatorname{Diet}^{\mathrm{a}}$} \\
\hline & \multirow[t]{2}{*}{ Basal } & \multicolumn{3}{|c|}{+ L-lysine and DL-methionine } & \multirow[t]{2}{*}{ SEM } & \multirow[t]{2}{*}{$P$} \\
\hline & & Low & Medium & High & & \\
\hline Initial body weight (kg) & 20.1 & 20.0 & 20.8 & 19.6 & 0.4 & 0.247 \\
\hline Final body weight (kg) & $68.8 \mathrm{a}$ & $72.6 \mathrm{a}$ & $80.3 b$ & $74.2 \mathrm{a}$ & 1.5 & 0.001 \\
\hline Average daily gain (g/day) & $537 \mathrm{a}$ & $584 \mathrm{a}$ & $660 \mathrm{~b}$ & $604 b$ & 17 & 0.001 \\
\hline Dry matter intake (kg/day) & $1.60 \mathrm{a}$ & $1.59 \mathrm{a}$ & $1.71 \mathrm{~b}$ & $1.64 \mathrm{ab}$ & 0.02 & 0.001 \\
\hline Feed conversion ratio ( $\mathrm{kg} \mathrm{DM} / \mathrm{kg}$ gain) & $2.99 \mathrm{a}$ & $2.73 b$ & $2.59 \mathrm{~b}$ & $2.72 b$ & 0.06 & 0.001 \\
\hline \multicolumn{7}{|l|}{ Calculated deposition (g/day) } \\
\hline Protein & $59.6 \mathrm{a}$ & $71.9 \mathrm{ab}$ & $84.3 b$ & $73.3 b$ & 3.5 & 0.001 \\
\hline Fat & 199.5 & 183.7 & 192.8 & 192.0 & 3.9 & 0.063 \\
\hline Feed cost ${ }^{\mathrm{a}}$ (VND/kg gain) & 6,482 & 6,269 & 6,193 & 6,692 & 145 & 0.099 \\
\hline Costs compared to control (\%) & 100 & 96.7 & 95.5 & 103 & - & - \\
\hline
\end{tabular}

Means with different letters within rows differ $(P<0.05)$. Supplementation with L-lysine and DL-methionine during the growing phase $(20-50$ and $50-80 \mathrm{~kg}$ ) in \% DM: low level, 0.10 and 0.05 and 0.05 and 0.03 ; medium level, 0.20 and 0.10 and 0.10 and 0.05 ; and high level, 0.3 and 0.15 and 0.15 and 0.08

${ }^{\text {a }}$ Price of feed ingredients in Hue at the time of the study in Viet Nam Dong (VND per kilogramme): ensiled cassava root, 400; ensiled cassava leaves, 500; rice bran, 2,200; maize, 2,200; fish meal, 6,000; DL-methionine, 65,000; L-lysine, 75,000. US $\$ 1=15,500 \mathrm{VND}$ 
diets ranged from $29.3-43.5 \mathrm{mg} / \mathrm{kg}$ DM. In the body, cyanide is detoxified by the enzyme rhodanese, forming thiocyanate, which is excreted in the urine (Oke 1978; Tewe et al. 1977).

The estimated fat and protein deposition of $F_{1}$ (Large White $\times$ Mong Cai) pigs were significantly affected by the dietary treatment. The data in Table 4 show that protein deposition in the DL-methionine supplemented diets were higher than in the control animals. Increased levels of supplementary methionine decreased fat deposition because at the same ME intake, less of the MEp is available for lipid gain. Supplementation with $0.15 \%$ methionine gave the highest protein deposition among diets although this was not significantly different from the protein deposition of the pigs fed the control $+0.10 \%$ methionine diet. These results confirm the studies by Eggum (1970) who reported that addition of synthetic methionine to diets for rats increased the biological value of cassava protein. Loc (2004) studied the addition of DL-methionine $(0 \%, 0.1 \%, 0.2 \%$ and $0.3 \%)$ to diets containing $20 \%$ to $40 \%$ of the DM ensiled cassava root to $F_{1}$ (Large White $\times$ Mong Cai) pigs. This author showed that an increased performance, as measured by growth rate and feed conversion ratio could be achieved with DL-methionine supplementation. In the present study, supplementary DL-methionine at $0.05 \%, 0.10 \%$ and $0.15 \%$ in diets containing $45 \%$ (in DM) ensiled cassava $(30 \%$ $\mathrm{ECR}+15 \% \mathrm{ECL}$ ) reduced the feed cost by $2.6 \%, 7.2 \%$ and $7.5 \%$, respectively.

Study 2 was designed to test whether further increases in performance can be obtained by adding lysine to methionine-supplemented ensiled cassava leaves and rootcontaining diets. Identical methionine supplementation levels were used compared to study 1 . Table 5 shows that supplementary L-lysine and DL-methionine in diets of growing pigs improved ADG, FCR and protein deposition. In this study, final $\mathrm{BW}, \mathrm{ADG}$ and protein deposition were highest at the two highest levels of supplementation (medium and high). The FCR and protein deposition were lower in the control diet than in the other three diets with supplemented L-lysine and DL-methionine. The final BW, ADG and protein deposition of the pigs were highest, and the FCR was the lowest at the medium level of supplementation with lysine and methionine. It appears that those levels met the requirements for lysine and methionine+ cysteine for growing $\mathrm{F}_{1}$ (Large White $\times$ Mong Cai) pigs. The content of lysine and methionine in the high supplemented diet was somewhat higher than the requirements for lysine and methionine as set by (NRC 1998). The reason for the numerical increase in FCR from the medium to the high level of supplementation is difficult to explain. Loc (2004) also found a slightly reduced daily gain of pigs fed $0.30 \%$ supplemental methionine compared to the $0.20 \%$ when fed an ensiled cassava root-based diet. In study 1 , no reduction in growth rate, FCR or protein deposition was observed indicating that this effect was likely due to the lysine addition instead of the methionine.

The most common procedures for reducing the cyanide content in cassava are sun drying and ensiling (Phuc et al. 2001; Borin et al. 2005; Nguyen et al. 2010b). Considerable amounts of cassava leaves are readily available as a byproduct at the time of harvesting the roots. However, in many tropical countries, the harvest season of cassava roots coincides with the rainy season making sun drying difficult or unfeasible. Ensiling is a suitable alternative way of preserving the roots and leaves (Van Man and Wiktorsson 2001, 2002) and recently Nguyen et al. (2010c) showed that ensiling cassava leaves for 90 days reduced the HCN concentration by $70-80 \%$. Our results in study 2 show that the diet supplemented with $0.20 \%$ L-lysine and $0.10 \%$ DLmethionine, and $0.10 \%$ L-lysine and $0.05 \%$ DL-methionine in the growing and finishing periods, respectively, resulted in the highest economic returns for farmers.

The present study further develops the practical and economical feasibility of using ensiled cassava leaves in diets for pigs. By supplementing diets containing ensiled cassava leaves with methionine and lysine, the performance of Large White $\times$ Mong Cai pigs can be significantly increased as well as the economic benefits for farmers.

Acknowledgements The financial support for this study was provided by the MEKARN programme supported by the Swedish International Development Cooperation Agency, Department for Research Co-operation (SIDA-SAREC) and the Centro Internacional de Agricultura Tropical (CIAT).

Open Access This article is distributed under the terms of the Creative Commons Attribution Noncommercial License which permits any noncommercial use, distribution, and reproduction in any medium, provided the original author(s) and source are credited.

\section{References}

An, L.V., Hong, T.T.T.and Lindberg, J.E., 2004. Ileal and total tract digestibility in growing pigs fed cassava root meal diets with inclusion of fresh, dry and ensiled sweet potato leaves. Journal of Animal Feed Science and Technology. 114, 127-139.

AOAC. 1990. Official methods of analysis. $15^{\text {th }}$ edition. Association of Official Analytical Chemists, Arlington, Virginia.

Borin, K., Lindberg, J. E. and Ogle, R. B., 2005. Effect of variety and preservation method of cassava leaves on diet digestibility by indigenous and improved pigs. Animal Science, 80, 319-324.

Cardoso, A. P., Mirione, M., Ernesto, M., Massaza, F., Cliff, J., Haque M. and Bradbury, H., 2005. Processing of cassava roots to remove cyanogens. Journal of Food Composition Analysis. 18, 451-460.

Chauynarong, N., Elangovan, A.V. and Iji., P. A., 2009. The potential of cassava products in diets for poultry. World's Poultry Science Journal, 65, 23-35.

Eggum, B. O., 1970. The protein quality of cassava leaves. British Journal of Nutrition, 24, 761-769. 
Gomez, G., Valdivieso, M. and Noma, A. T. 1985. The influence of cultivar and plant age on the chemical composition of fieldgrown cassava leaves and roots. Plant Food for Human Nutrition, $35,109-119$.

Job, T. A. 1975. Utilization and protein supplementation of cassava for animal feeding and the effect of sulfur source on cyanide detoxification. PhD Thesis. University of Ibadan, Nigeria.

Kotarbinska, M. and Kielanowski, J., 1969. Energy balance studies with growing pigs by the comparative slaughter technique. Proceeding of the $4^{\text {th }}$ symposium on energy metabolism. Warsaw. EAAP publication, 12, 299-310.

Loc, N. T. 2004. Study on ensiling technique and utilization of ensiled cassava root with inclusion of DL-methionine in diets for crossbred pigs (Large White x Mong Cai). Doctoral Thesis. Ministry of Education and Training, Hue University, Vietnam. 158 p.

Mintab Reference Manual. 2004. Release 14 for Windows. Minitab Inc., USA.

Montagnac, J. A., Davis, C. R. and Tanumihardjo, S. A., 2009. Nutritional value of cassava for use as a staple food and recent advances for improvement. Comprehensive Reviews in Food Science and Food Safety, 8, 186-194.

Moore, S. 1963. On the determination of cystine as cysteic acid. Journal of Biological Chemistry, 238, 235-237.

Ngoan, L. D. and Lindberg, J. E., 2001. Ileal and total tract digestibility in growing pigs fed cassava root meal and rice bran diets with inclusion of fish meal and fresh or ensiled shrimp by-products. AsianAustralian Journal of Animal Science, 14, 216-223.

Ngudi, D. D., Kuo, Y. H. and Lambein, F., 2003. Cassava cyanogens and free amino acids in raw and cooked leaves. Food Chemical Toxicology, 41, 1193-1197.

Nguyen. T. H. L., Ngoan, L. D., Verstegen, M. W. A. and Hendriks, W. H., 2010a. Ileal and total tract apparent protein and amino acid digestibility of ensilage and dry cassava leaves and sweet potato vines in growing pigs. Journal of Animal Feed Science and Technology (in press).

Nguyen. T. H. L., Ngoan, L. D., Verstegen, M. W. A. and Hendriks, W. H., 2010b. Ensiled and dry cassava leaves, and sweet potato vines as a protein source in diets for growing Vietnamese Large White x Mong Cai pigs. Asian-Australian Journal of Animal Science, 23, 1205-1212.

Nguyen. T. H. L., Ngoan, L. D., Verstegen, M. W. A. and Hendriks, W. H., 2010c. Ensiling techniques for preserving cassava leaves. Journal of the Science of Food and Agriculture (submitted).
NIAH (National Institute of Animal Husbandry). 2001. Composition and Nutritive Value of Animal Feeds in Vietnam. Agriculture Publishing House, Hanoi. P. 391.

NRC (National Research Council), 1998. Nutrient Requirements of Swine. $10^{\text {th }}$ Ed., National Academy of Sciences, Washington, D.C.

Oke, O. L. 1978. Problems in the use of cassava as animal feed. Journal of Animal Feed Science and Technology, 3, 345-380.

Phuc, B. H. N. 2000. Tropical Forages for Growing Pigs. Ph.D. Thesis, Swedish University of Agricultural Sciences Uppsala, Sweden.

Phuc, B. H. N. and Lindberg, J. E., 2001. Ileal digestibility of amino acids in growing pigs given cassava root meal diets with inclusion of cassava leaves, leucaena leaves and groundnut foliage. Animal Science, 72, 511-517.

Phuc, B. H. N., Lindberg, J. E., Ogle, B. and Thomke, S., 2001. Determination of the nutritive value of tropical biomass products for monogastrics using rats. Part 2. Effects of drying temperature, ensiling and level of inclusion of cassava leaves and sweet potato vines. Asian-Australian Journal of Animal Science, 14, 994-1002.

Ravindran, V., 1993. Cassava leaves as animal feed: Potential and limitations. Journal of the Science of Food and Agriculture, 41, 45-53.

Spackman, D.H., Stein, W.H. and Moore, S., 1958. Automatic recording apparatus for use in chromatography of amino acids. Analysis Chemistry. 30, 1190-1206.

Tewe, O. O., 1992. Detoxification of cassava products and effects of residual toxins on consuming animals. In: Roots, tubers, plantains and bananas in animal feeding. (D. Machin and S. Nyvold, editors) FAO Animal Production and Health Paper No 95. Rome, 81-98

Tewe, O. O., Maner, J. H. and Gomes, G., 1977. Influence of cassava diets on placental thiocyanate transfer, tissue rhodanase activity and performance of rats during gestation. Journal of the Science of Food and Agriculture, 28, 750-756.

Van Man, N. and Wiktorsson. H., 2001. Cassava tops ensiled with or without molasses as additive effects on quality, feed intake and digestibility by heifers. Asian-Australian Journal of Animal Science, 14, 624-630.

Van Man, N. and Wiktorsson, H., 2002. Effect of molasses on nutritional quality of cassava and gliricidia tops silage. AsianAustralian Journal of Animal Science, 15, 1294-1299. 